Original Research

\title{
Music Therapy and Bibliotherapy to Reduce Child Anxiety When Given Intravenous Therapy
}

\section{Heryyanoor Heryyanoor'1, Muhsinin Muhsinin'2, Rahmawati Rahmawati ${ }^{3}$, Fitriyanti Patarru' ${ }^{1}$, Febrina Secsaria Handini ${ }^{1}$, and Basilius Yosepfus Weu ${ }^{1}$}

${ }^{1}$ Faculty of Nursing, Universitas Airlangga, Surabaya, Indonesia

2Faculty of Nursing and Health Sciences Muhammadiyah University, Banjarmasin, Indonesia

${ }^{3}$ Health Polytechnic Ministry of Health, Banjarmasin, Indonesia

\begin{abstract}
Introduction: Children often experience anxiety when undergoing the treatment process at the hospital. Efforts to reduce such anxiety can be done with music therapy and bibliotherapy. This study aims to analyze the differences in the effectiveness of music therapy and bibliotherapy in reducing anxiety in children before getting intravenous therapy.
\end{abstract}

Methods: The research design was quasi-experimental, with the pretest and posttest approach. The population was 178 with 32 samples, each of the 16 respondents were given music therapy and bibliotherapy using a purposive sampling technique. Data were collected with observation sheets from the adoption of the HAM-A scale, analyzed by the Wilcoxon test and independent $\mathrm{T}$ test at a significance level of $\mathrm{p} \leq 0.05$.

Results: There were differences in children's anxiety when getting intravenous therapy before and after music therapy and bibliotherapy with $p=0.001$ ( $p<0.05)$, and there was no difference in the effectiveness of the two $p$ values $=0.91(p>0.05)$, but the average bibliotherapy reduced anxiety by $65 \%$, and music therapy by $57 \%$.

Conclusion: Bibliotherapy can be given as complementary therapy in children before intravenous therapy.

\section{ARTICLE HISTORY}

Received: Dec 26, 2019

Accepted: Dec 31, 2019

\section{KEYWORDS}

music therapy; bibliotherapy; anxiety; anxiety; intravenous therapy

\section{CONTACT}

Heryyanoor Heryyanoor

$\triangle$ heryyanoor-2018@fkp.unair.ac.id $\fallingdotseq$ Faculty of Nursing, Universitas Airlangga, Surabaya, Indonesia

Cite this as: Heryyanoor, H., Muhsinin, M., Rahmawati, R.,, Patarru', F., Handini, F.S., \& Weu, B.Y. (2019). Music Therapy and Bibliotherapy to Reduce Child Anxiety When Given Intravenous Therapy. Jurnal Ners, 14(3si), 345-353. doi:http://dx.doi.org/10.20473/jn.v14i3(si).17182

\section{INTRODUCTION}

Children are individuals who are in a range of developments ranging from babies to teenagers and who have specific physical, psychological, social, and spiritual needs that are different from adults. These needs must be fulfilled so that they are successful and healthy, because if the illness affects the growth, physical, psychological, intellectual, social, and spiritual development that increases in the hospitalization process (Yupi Supartini . Msc, 2004).

Hospitalization is a process that requires children to stay in the hospital, evaluate therapy and care to return home (Yupi Supartini . Msc, 2004). Hospitalization is the main cause of stress for patients, including pediatric patients who cause concern (Ghabeli, Moheb, \& Hosseini Nasab, 2014)
Anxiety is a difficult, handled, and anxiety situation in response to stress or uncertain movement (Scholten \& Randall, 2013). Children's anxiety is manifested by feelings of discomfort or care in the most basic response, given when given invasive medical therapy such as intravenous therapy and blood sampling which is the initial example of admission to hospital.

Giving intravenous therapy causes a trauma response in children, especially children aged 3-12 years who usually express as moaning and whining, angry, withdrawn, and hostile reactions that can be expressed verbally (Wilson, 2016). The next process of action in the hospital treatment process, especially when given intravenous drug delivery therapy or other actions, causes the child to be uncooperative, because the child's memory of previous pain 
experience when given intravenous therapy (Gosia M. Brykczynska, 2011), and the fear of children for recurring pain in something that hurts his body (Debra L. Price, MSN, RN, CPNP and Julie F. Gwin, MN, 2012).

The last two decades the prevalence of children admitted to hospitals has rapidly increased and has more serious and complex problems compared to previous years (Donna L. Wong [et.all], 2008). In the United States, it is estimated that more than 5 million children experience hospitalization and more than $50 \%$ of these children experience anxiety and stress (Kain ZN1, Mayes LC, Caldwell-Andrews AA, Karas $\mathrm{DE}, 2006)$. Interviews conducted at 6 children in hospitals in the UK found that children aged 10-13 years with various chronic conditions revealed fear of invasive procedures, injections, surgery, fear of death, loss of control and freedom. Of the 17 children aged 7-16 years in 3 hospitals in Ireland with 7 children suffering from chronic diseases and 10 of children suffering from acute illness reported anxiety about injection procedures, blood tests and pain (Gosia M. Brykczynska, 2011).

In Indonesia $30 \%$ of 180 children aged 3-12 years have experience with hospitals and an estimated 35 per 1000 children undergo hospitalization. The results of the National Health Survey, Morbidity Rate for children aged 5-12 years were $14.91 \%$ or around $14.44 \%$ of the total population of $237,641,326$ people. The data was supported by the 2012 annual UNICEF (United Nations Children's Fund) report which explained that the child poverty rate in Indonesia was around 44.4 million or more than $50 \%$ of all children, even greater than the adult poverty rate. Child health problems that are common in Indonesia and which remain high are diseases caused by environmental problems such as dengue hemorrhagic fever, diarrhea, intestinal worms, and acute respiratory infections and adverse reactions to food due to poor sanitation and food security (Judarwanto, 2005).

The survey results on the 25th and 26th of September 2014 in the children's room of Ratu Zalecha Martapura Public Hospital found that the number of pediatric patients in 2012 was 2343 and in 2013 as many as 2039. In 2014 from January to September 242014 there were 1758. Children treated since in last 3 months (July to September) amount to 643 , and specifically in July to September 24,2014 the number of preschoolers (3-5 years) 441 and school age (6-12 years) total 92 or an average of 147 and 31 patients every month. The observation of 15 children who were given intravenous drug treatment, $46.7 \%$ (7 children) cried loudly and rebelled by trying to avoid, $0.06 \%$ ( 1 child) crying and restless, and $46.7 \%$ (7 children) ) frown. Verbal expressions spoken by children before being given therapy include "What for? ; What are you doing, Mama? ; Pain ", while nonverbal refused to be touched, cried when touched and woke up from sleep, and embraced his parents when he just met the nurse. The results of interviews conducted on 5 of the 15 children observed, $100 \%$ complained of pain when given intravenous drug delivery therapy and expressed the desire to go home soon.

This condition is a manifestation of children's anxiety as a result of hospitalization. Anxiety that occurs in children when given intravenous drug administration therapy is due to trauma over previous experience when given intravenous therapy that causes pain. They do not understand why they should be treated and the unpreparedness of the child to face something new, a foreign environment that has never been encountered before, which is different from the atmosphere of the house and the unknown care provider. As a result children feel insecure and comfortable, feel lost something that is usually experienced, different habits, or separation from peers, and family and nursing actions that are very painful for children (Yupi Supartini . Msc, 2004). These conditions if not addressed properly can cause tension, fear and can cause emotional or behavioral disorders that ultimately affect recovery and the child's illness journey during hospitalization.

Attempts to process the environment can be done by nurses to be able to minimize stress on children so that it does not become a crisis, especially when giving a medical action. This is because preparing the psychological condition of a child prior to nursing action is very important. Many methods can be used by nurses to minimize anxiety, including using music therapy and bibliotherapy.

Music therapy is a complementary therapy that is used in the health sector to evaluate and treat patients with emotional, physical, cognitive, and social function disorders (Maratos, Gold, Wang, \& Crawford, 2008). The use of music as a health therapy or treatment is because music has a therapeutic aspect by stimulating stimulation, where the music enters the mind through an auditory sensation with a soft voice that can reduce stress, pain perception, anxiety and feelings of isolation. The results of the study found that the successor nerves of the music and the successor nerves of pain were the same (Musbikin, 2009), and confirmed by the results of Nurul Sri Wahyuni (2004) that there was an effect of music therapy on the decrease in anxiety levels with a value $(p=0,000)$ and the average decrease in anxiety level is 4.05 .

Bibliotherapy is an action that is projected by using thematic books or any reading such as biography, novels, poetry, short stories to help children overcome changes, emotional and mental problem (Lucas \& Soares, 2013). Bibliotherapy helps children to think and understand the situation they experience, in other words being able to act as a therapeutic treatment (Nicki L. Potts, 2011)

The tendency of children to identify the characters in the story, making bibliotherapy become a tool that has full strength to help normalize the feeling of loss and pain experienced (Austin, 2010). This provides an example of coping in the hope that children will get joy again and reduce anxiety during the hospitalization process, especially when they will be given nursing action. This is supported by the results 
of the study of Anita Apriliawati (2011) who concluded that there was an influence of Bibliotherapy on the decrease in anxiety levels with a value $(\mathrm{p}=0,000)$ with an average decrease in anxiety level of 5.33 .

Based on the urain it can be concluded that music therapy and bibliotherapy can reduce anxiety in children who undergo the hospitalization process, especially when they will be given nursing action. Both methods can be easily implemented by nurses in providing hospital services by involving families and or parents of children in order to increase the intensity of service time, because basically the intensity of service to pediatric patients is $20-45 \%$ more than adults (Aidar, 2011)

The effectiveness between the two methods is not much different only around 1.28 , so it needs to be further investigated to be applied in a simple manner in the hospital as one of the interventions in providing nursing services to children who, as far as the researchers know, have not yet done so. Especially with the statement of 3 (three) nurses in the Children's Room of Ratu Zalecha Martapura Hospital who said that "music therapy and bibliotherapy have never been given to pediatric patients, we only provide play therapy such as drawing and coloring, writing, and playing dolls". Based on this, the researchers argue that this research can be applied in hospitals later.

\section{MATERIALS AND METHODS}

The design of this research is Quasy Experimental with Pretest and Posttest Design. Population 178 with a sample of 32 , each 16 respondents were given classical music therapy with a choice of titles: 1) Helps Baby Relax \& Fall Asleep FAST; 2) Relaxing Sunrise with Meditation Music; 3) This Mozart for Baby does not make my baby sleep like an angel. Bibliotherapy by projecting children's perceptions of the hospitalization process accompanied by Book 50 Stories of World Fable Stella Ernes or Tales of the Kancil and Her Friends, Fatiharifah and Nisa Yustisia. Sampling uses Purposive Sampling.

Data were collected by observation sheet of the results of the adoption of the HAM-A scale (Hamilton Anxiety Rating Scale) that has been modified / adopted into 6 situations, namely: 1) Children try to avoid when the nurse comes over / anticipates fear; 2) The child jerks when the hand is touched by the nurse; 3 ) Children's voices falter when given nursing intervention; 4) Does not show interest in activities / invited to interact (looks weak); 5) Rapid breathing / Choking when given nursing intervention; and 6) Crying loudly / groaning when given intravenous therapy. Analysis with Wilcoxon test and Independent $\mathrm{T}$ test with significance level $\mathrm{p} \leq 0.05$.

\section{RESULTS}

The results of the study were based on the respondents' characteristics as many as 32 samples taken through Purposive Sampling techniques by considering inclusion criteria with parental consent of a population of 178 (Table 1).

Based on the table above shows that the majority of respondents aged 6-12 years as many as 21 pediatric patients (65.6\%), male sex as many as 18 pediatric patients $(56.2 \%)$, first time treated as many as 15 patients children (46.9\%), while the majority of medical diagnoses were febrile as many as 11 pediatric patients (34.4\%), children accompanied by both parents (father and mother) were 25 pediatric patients $(78.1 \%)$ and had undergone treatment on the second day there were 12 pediatric patients (37.5\%).

The results of the study are based on differences in the effectiveness of anxiety in patients with children aged 3-12 years when given Intravenous Therapy Before and After Music Therapy and Bibliotherapy are given in Table 2.

From the data it is known that out of 16 respondents who will be given Intravenous Therapy before being given music therapy, all (100\%) experience severe anxiety with a score range of 4-6 and an average score of anxiety 4.94. After being given music therapy, respondents who experienced severe anxiety became 6 children (37.5\%) with a score range of $0-3$ and an average of 2.13. This means that there was a decrease in the average anxiety of $2.81(57 \%)$ after being given music therapy.

The decrease in anxiety that occurs specifically is seen in the situation. Children do not avoid when the nurse comes over / anticipates fear with a percentage of $100 \%$, the child's breathing pattern becomes regular / no longer choked with a $66.7 \%$ decrease in the child. percentage decrease of $57.1 \%$, crying loudly / groaning when given intravenous therapy $56.2 \%$, children do not show interest in activities / invited to interact (looks weak) with a percentage decrease of $50 \%$, and children's voices faltering / frowning when given nursing intervention $49,9 \%$.

Analysis by Wilcoxon test $\mathrm{p}=0.001(\mathrm{p}<0.05)$ which means $\mathrm{H}$ berarti is rejected. So it was concluded that there was a difference in anxiety between 3-12 year olds when given intravenous therapy in the Queen Room of Ratu Zalecha Martapura Hospital before and after being given music therapy, meaning music therapy had an effect on reducing child anxiety when they were given intravenous therapy.

In addition to these data it is also known that of the 16 respondents who will be given Intravenous Therapy before being given Bibliotherapy, 11 children (68.8\%) experienced severe anxiety with a score range of 4-6 and an average score of anxiety of 4.25. After being given music therapy, respondents who experienced severe anxiety became 5 children (31.2\%) with a score range of $0-3$ and an average of 1.5. This means there is a decrease in the average anxiety of 2.75 (65\%) after being given Bibliotherapy.

The decrease in anxiety that occurs specifically seen in the child's situation does not flinch when his hand is touched by the nurse and shows interest in activities / invited to interact 93.8\%, the child does not avoid when the nurse comes over / anticipates 
Table. 1. Distribution of Respondents Based on the Characteristics of Children of the Age 3-12 years who were given Intravenous Therapy in the Children's Room of Ratu Zalecha Martapura Hospital in 2015.

\begin{tabular}{|c|c|c|c|c|c|}
\hline No. & Karakteristik & $\mathbf{N}$ & Kategori & $\mathbf{F}$ & Person (\%) \\
\hline \multirow[t]{2}{*}{1.} & Age & 32 & $3-5$ years & 11 & 34,4 \\
\hline & & & 6-12 years & 21 & 65,6 \\
\hline \multirow[t]{2}{*}{2.} & Gender & 32 & Man & 18 & 56,2 \\
\hline & & & Women & 14 & 43,8 \\
\hline \multirow[t]{4}{*}{3.} & Nursing experience & 32 & The first time & 15 & 46,9 \\
\hline & & & Second & 11 & 34,4 \\
\hline & & & Third & 4 & 12,5 \\
\hline & & & Fourth & 2 & 6,2 \\
\hline \multirow[t]{6}{*}{4.} & Type of disease & 32 & Asthma & 1 & 3,1 \\
\hline & & & Dengue Hemorrhagic Fever & 6 & 18,8 \\
\hline & & & Febris & 11 & 34,4 \\
\hline & & & Gastrointestinal & 2 & 6,2 \\
\hline & & & Febrile convulsion & 4 & 12,5 \\
\hline & & & Typhoid & 8 & 25 \\
\hline \multirow[t]{3}{*}{5.} & Parent's Side by Side & 32 & Accompanied by father & 2 & 6,2 \\
\hline & & & Accompanied by mother & 5 & 15,6 \\
\hline & & & Accompanied by Father and Mother & 25 & 78,1 \\
\hline \multirow[t]{3}{*}{6.} & Nursing Day & 32 & First & 11 & 34,4 \\
\hline & & & Second & 12 & 37,5 \\
\hline & & & Third & 9 & 28,1 \\
\hline
\end{tabular}

Table. 2. Anxiety Distribution of 3-12 year-old Children Patients who were given Intravenous Therapy Before and After were given Music Therapy in the Children's Room of Ratu Zalecha Martapura Hospital in 2015.

\begin{tabular}{|c|c|c|c|c|c|c|c|c|c|c|c|}
\hline \multirow[t]{2}{*}{ Res } & \multicolumn{5}{|c|}{ Treatment with Music Therapy } & \multirow[t]{2}{*}{ Res } & \multicolumn{5}{|c|}{ Treatment with Bibliotherapy } \\
\hline & $\begin{array}{l}\text { Before } \\
\text { Score }\end{array}$ & Category & $\begin{array}{l}\text { After } \\
\text { Score }\end{array}$ & Category & $\begin{array}{l}\text { Differen } \\
\text { ce } \\
\text { Decline }\end{array}$ & & $\begin{array}{l}\text { Before } \\
\text { Score }\end{array}$ & Category & $\begin{array}{l}\text { After } \\
\text { Score }\end{array}$ & Category & $\begin{array}{l}\text { Differe } \\
\text { nce } \\
\text { Decline }\end{array}$ \\
\hline 1 & 4 & Weight & 0 & Light & 4 & 1 & 6 & Weight & 4 & Weight & 2 \\
\hline 2 & 6 & Weight & 0 & Light & 6 & 2 & 6 & Weight & 4 & Weight & 2 \\
\hline 3 & 5 & Weight & 4 & Weight & 1 & 3 & 4 & Weight & 0 & Light & 4 \\
\hline 4 & 4 & Weight & 0 & Light & 4 & 4 & 6 & Weight & 2 & Light & 4 \\
\hline 5 & 4 & Weight & 1 & Light & 3 & 5 & 3 & Light & 0 & Light & 3 \\
\hline 6 & 5 & Weight & 4 & Weight & 1 & 6 & 6 & Weight & 4 & Weight & 2 \\
\hline 7 & 5 & Weight & 5 & Weight & 0 & 7 & 5 & Weight & 0 & Light & 5 \\
\hline 8 & 5 & Weight & 3 & Light & 2 & 8 & 4 & Weight & 0 & Light & 4 \\
\hline 9 & 5 & Weight & 4 & Weight & 1 & 9 & 4 & Weight & 1 & Light & 3 \\
\hline 10 & 4 & Weight & 1 & Light & 3 & 10 & 3 & Light & 0 & Light & 3 \\
\hline 11 & 4 & Weight & 0 & Light & 4 & 11 & 4 & Weight & 4 & Weight & 0 \\
\hline 12 & 6 & Weight & 4 & Weight & 2 & 12 & 5 & Weight & 1 & Light & 4 \\
\hline 13 & 5 & Weight & 1 & Light & 4 & 13 & 3 & Light & 0 & Light & 3 \\
\hline 14 & 6 & Weight & 4 & Weight & 2 & 14 & 2 & Light & 0 & Light & 2 \\
\hline 15 & 5 & Weight & 0 & Light & 5 & 15 & 5 & Weight & 4 & Weight & 1 \\
\hline 16 & 6 & Weight & 3 & Light & 3 & 16 & 2 & Light & 0 & Light & 2 \\
\hline $\begin{array}{l}\mathrm{Me} \\
\text { an }\end{array}$ & 4,94 & & 2,13 & & $\begin{array}{l}2,81 \\
(57 \%)\end{array}$ & Mean & 4,25 & & 1,5 & & $\begin{array}{l}2,75 \\
(65 \%)\end{array}$ \\
\hline Uji W & lcoxon & $=0,001$ & & & & Uji Wil & on $: p=$ & 0,001 & & & \\
\hline
\end{tabular}

fear with an $80.1 \%$ percentage, crying loudly / whimpering when given $60 \%$ intravenous therapy, the child's breathing pattern becomes regular / no longer choking with a percentage decrease of $58.4 \%$, and the child's voice faltering / frowning when given a $40 \%$ nursing intervention.

Statistical analysis with the Wilcoxon test obtained a value of $\mathrm{p}=0.001(\mathrm{p}<0.05)$ which means $\mathrm{H}_{\mathrm{o}}$ was rejected. So it can be concluded that there is a difference in anxiety between 3-12 year old children when given intravenous therapy in the Queen Zalecha Martapura Hospital Children's Room before and after the Bibliotherapy was given, meaning Bibliotherapy has an effect on reducing child anxiety when given intravenous therapy.

The average percentage decrease in the anxiety of the given bibliography is $2.75(65 \%)$, or given music therapy which is 2.81 (57\%). The statistical analysis using the Independent Sample Test obtained $\mathrm{p}=0.91$ ( $p>0.05$ ) which means $\mathrm{H}_{\mathrm{o}}$ is accepted. So it can be concluded that there is no difference between therapy and those given by bibliotherapy. The therapy is in the Children's Room of the Queen Zalecha Martapura Hospital 


\section{DISCUSSION}

An overview of the characteristics of respondents based on age, gender, previous treatment experience, type of illness, assisted parents, day of care for children aged 3-12 years In general, the number of respondents was 32 children, each of which $50 \%$ of children were given music therapy and were given bibliotherapy. The majority of children aged 6-12 years as many as $65.6 \%$, male sex $56.2 \%$, and the first time undergoing treatment at the hospital $46.9 \%$, the type of disease (diagnosis) Febris 34.4\%, accompanied both parents (father and mother) $78.1 \%$, and second day care $37.5 \%$.

All respondent characteristics are factors that influence children's anxiety during the hospitalization process. Decreased anxiety of respondents given bibliotherapy before children were given Intravenous Therapy by $65 \%$ and those given music therapy by $57 \%$. This is influenced by the characteristics of the respondents themselves.

Respondents aged 6-12 years experienced severe anxiety of $47.6 \%$ compared to 3-5 years of age of only $9.1 \%$. This is not in accordance with the opinion of Mansur (2007) which states that the older a person is, the better he is in controlling his emotions.

Respondents male sex $56.2 \%$ majority experienced severe anxiety $38.9 \%$ compared to women who only $28.6 \%$. This is because women in responding to external stimuli or stimuli are more sensitive than men, so they influence their coping mechanisms (Kurniawan, 2008).

Respondents with first-time experience in hospital care were $46.9 \%$ basically experiencing severe anxiety $40 \%$ compared to subsequent experiences, but this condition could also occur in respondents who had already undergone hospital treatment. This is influenced by various other factors such as the type of disease, parental assistance, and children's perceptions in responding to pain responses.

The most types of diseases / medical diagnoses experienced by respondents were Febris $34.4 \%$, but those who experienced severe anxiety were $50 \%$ of children with DHF (Dengue Fever). This is because dengue is a relatively severe disease, this dengue virus infection caused by the aedes agypty mosquito causes fever, bleeding, shock, and can even lead to death.

Parental facilitation affects children's anxiety during hospitalization, respondents who were only accompanied by their father $100 \%$ more experienced severe anxiety, compared to children accompanied by their mothers with a weight of only $20 \%$. This is because the mother is the closest figure to the child compared to the father.

The length of the treatment day affected anxious children, in this study children with care on the third day experienced severe anxiety $55.6 \%$ or increased on the first day of treatment $18.2 \%$ and secondly $33.3 \%$. This is due to trauma factors over the treatment of intravenous therapy, especially those that are invasive and the perception of children who consider the hospitalization process to be a punishment for him.

Anxiety of Children Patients aged 3-12 years who were given Intravenous Therapy in the Children's Room of Ratu Zalecha Martapura Hospital in 2015 before and after being given music therapy. Anxiety of Children Patients Aged 3-12 years who were given Intravenous Therapy based on the Anxious Response of Children before being given music therapy $100 \%$ experienced severe anxiety with a score range of 4-6. While the average anxiety score of children from 6 situations / anxiety is 4.94 .

The child's anxiety is seen in the situation when the nurse will provide Intravenous Therapy. The response that occurs is: the child does not show interest in the activity / invited to interact (looks weak) and crying loudly / moaning when given intravenous therapy shows anxiety $100 \%$, rapid breathing / choking when given nursing intervention $93.8 \%$, the child jerks when his hand is touched nurses, children's voices faltered when given a nursing intervention of $87.5 \%$, and the child tried to avoid when the nurse came over / anticipated fear by $25 \%$.

This is in accordance with the theory that physical symptoms that appear in anxious states such as fatigue, rapid heartbeat, sweating (especially on the palms), muscle tension, shortness of breath / increased frequency of breathing, choking (Scholten \& Randall, 2013). According to Carpenito (2007) symptoms of anxiety can be seen from situations of fear, helplessness, nervousness, loss of control, apparent tension seen in children with excessive anger, loud crying, and rebellion.

The child's behavior is a symptom of anxiety, especially for children who have undergone hospitalization for the first time in the study as much as $46.9 \%$ and experience severe anxiety about $40 \%$, so the effects of trauma will be very meaningful and make the hospital environment including health workers a threat to him. This situation occurs because the child feels threatened when given intravenous therapy which is usually manifested by feeling uncomfortable or painful as the most basic response, especially when given invasive medical therapy such as intravenous therapy (infusion) and blood sampling that becomes initial action when the child is admitted to the hospital.

Giving intravenous therapy causes a trauma response in children, especially children aged 3-12 years who usually express moaning and whining, angry, withdrawn, and hostile reactions that can be expressed verbally (Hockenbery \& Wilson, 2009). In the next process in the hospital treatment process, especially when given intravenous drug treatment and other actions, children tend to be uncooperative. This is supported by the child's memory of previous pain experiences when given intravenous therapy (Brykczyinska \& Simons, 2011) and the existence of expressions of fear of children over recurring pain in something that hurts their body (Price \& Gwin, 2008). 
Efforts to reduce anxiety related to situations that occur in children when Intravenous Therapy will be given in this study, namely before children are given classical music therapy with a slightly slower tempo, 50 - 70 beats / minute, using a quiet rhythm (Schou, 2007), and with the minimum time range for giving is 10 minutes to 1 hour using speakers or cellphones. This is very easy for nurses to involve parents of children, because in principle therapists do not always need special skills (Suryana, 2012).

Providing music therapy to children undergoing hospitalization before intravenous therapy has been shown to reduce anxiety. The results of this study indicate that the Anxious Response of Children aged 3-12 years after being given music therapy who experienced severe anxiety became $37.5 \%$ with a score range of $0-3$ and an average of 2.13 . This shows that there was a decrease in the average anxiety of $2.81(57 \%)$ after being given music therapy.

The decrease in anxiety that occurs specifically also occurs in situations where children do not avoid when nurses come over / anticipate fear with a percentage of $100 \%$, the child's breathing pattern becomes regular / no longer choked with a $66.7 \%$ drop in percentage, the child does not jerk when the hands are touched by the nurse and showing interest in activities / invited to interact $57.1 \%$, children not crying loudly / moaning when given intravenous therapy $56.2 \%$, and the sound of children not wavering / not frowning when given nursing intervention $43.7 \%$.

The results of statistical analysis using the Wilcoxon test, of the 16 respondents it was known that there were 15 respondents (94\%) experienced a decrease in anxiety after being given music therapy, and 1 respondent whose anxiety remained. The value of $\mathrm{p}=0.001(\mathrm{p}<0.05)$ which means $\mathrm{H}_{\mathrm{o}}$ is rejected. So it can be concluded that there is a difference in Anxiety Decrease in Children aged 3-12 years when given Intravenous Therapy in the Children's Room of Ratu Zalecha Martapura Hospital in 2015 before and after being given music therapy. This means that music therapy is effective in reducing anxiety in children aged 3-12 years when intravenous therapy is given. The results of this study are in accordance with the results of previous studies conducted by Nurul Sri Wahyuni (2004) that there is an effect of music therapy on the decrease in anxiety levels with a value $(p=0,000)$ and an average decrease in anxiety level of 4.05 .

The use of classical music as a health therapy in medicine is because music has a therapeutic aspect by stimulating stimulation, where the music enters the mind through auditory sensations with a soft voice that can reduce stress, pain perception, anxiety and feelings of isolation (De Laune \& Ladner, 1998 ) This is because from the results of the study it was found that the successor nerves of the music and the successive nerves of pain are the same (Musbikin, 2009). In addition, classical music has a rhythm similar to the heart rhythm compared to pop music, disco, rock and roll, and other anapestic beat music
(2005) in Suryana (2012). So that it can affect the body and mind, especially in children aged 3-12 years who undergo the hospitalization process.

Classical music produces rhythmic stimuli which are then captured through the auditory organs and processed in the nervous system of the body and glands in the brain and then reorganizes sound interpretations into the internal rhythm of the listener. This internal rhythm affects the body's metabolism so that the process takes place better. Good metabolism will be able to build a better immune system, so that the body becomes more resilient to the possibility of disease attacks (Satiadarma, 2002).

These physiological changes occur due to the activity of two neuroendocrine systems controlled by the hypothalamus, namely the sympathetic system and the adrenal cortex system (Prabowo \& Regina, 2007). The hypothalamus is also called the brain stress center because of its dual function in an emergency. Its first function is to activate the sympathetic branches and autonomic nervous system. The hypothalamus delivers nerve impulses to the nuclei in the brain stem that control the functioning of the autonomic nervous system. The sympathetic branch of the autonomic nervous system reacts directly to smooth muscles and internal organs to produce several body changes such as an increase in heart rate and blood pressure as a response to anxiety. The sympathetic system also stimulates the adrenal medulla to release the hormone epinephrine (adrenaline) and norepinephrine into the blood vessels, thus impacting increasing heart rate and blood pressure, while norepinephrine indirectly through its action on the pituitary gland releases sugar from the liver. Adrenal Corticotropin Hormone (ACTH) stimulates the outer layer of the adrenal gland (the adrenal cortex) which causes the release of hormones (one of the main ones is cortisol / hormone that affects anxiety) which regulates glucose levels and certain minerals (Primadita, 2011).

One of the benefits of music as a therapy is selfmastery, the ability to control yourself. Music contains energy vibrations, these vibrations also activate cells in a person, so that by activating these cells a person's immune system is more likely to be active and increase its function. In addition, music can increase serotonin and the growth of hormones that are as good as reducing the hormone ACTH (Satiadarma, 2002). Giving classical music therapy makes a person relax, creates a sense of security and well-being, releases feelings of joy and sadness, releases pain and lowers stress levels, so that it can cause a decrease in anxiety (Musbikin, 2009). This happens because of a decrease in Ardenal Corticotropin Hormone (ACTH) which is a stress hormone (Djohan, 2006).

Decreased anxiety experienced by children after being given music therapy due to various factors. These factors include age, gender, previous treatment experience, type of illness, and parental assistance 
that has been explained previously on the characteristics of respondents.

It is evident from this study that these factors affect children's anxiety when given intravenous therapy. Boys experience anxiety weighing 38.9\% compared to women who are only $28.6 \%$. This is because women in responding to external stimuli or stimuli are more sensitive than men, so they influence their coping mechanisms (Kurniawan, 2008).

The first experience was basically treated with anxiety $40 \%$ compared to subsequent experiences, but this condition can also occur in respondents who have had treatment at the hospital. This is influenced by various other factors such as the type of disease, parental assistance, and children's perceptions in responding to pain responses.

Severe diseases, such as DHF (Dengue Hemorrhagic Fever) result in $50 \%$ of children experiencing severe anxiety. This is because DHF is a disease of dengue virus infection caused by the aedes agypty mosquito which causes various clinical symptoms such as fever, bleeding, shock, and even death.

Parental facilitation affects children's anxiety during hospitalization, respondents who were only accompanied by their father $100 \%$ more experienced severe anxiety, compared to children accompanied by their mothers with a weight of only $20 \%$. This is because the mother figure is the closest figure to the child compared to the father. Anxiety in Children Patients aged 3-12 years who were given Intravenous Therapy in the Children's Room of Ratu Zalecha Martapura Regional Hospital in 2015 before and after being given a Bibliotherapy. Anxiety of Children Patients aged 3-12 years who were given Intravenous Therapy based on the Anxious Response of Children before being given a Bibliotherapy 68.8\% experienced severe anxiety with a score range of 4-6. While the average anxiety score of children from 6 situations / anxiety is 4.25 .

The child's anxiety is apparent in the situation when the nurse will provide Intravenous Therapy. The response was specifically, $100 \%$ of children showed no interest in activities / invited to interact (looking weak), crying loudly / moaning when given 93.8\% intravenous therapy, rapid breathing / choking when given $75 \%$ nursing intervention, the child jerks when his hand touched by the nurse, the child's voice faltered / frowned when given $62.5 \%$ nursing intervention, and the child tried to avoid when the nurse came over / watched fear 31.2\%.

The response above is a situation that describes children's anxiety during the hospitalization process, this is in accordance with Wong's opinion (2009) which is included in the child's protest phase. In this phase observable behaviors such as crying, screaming, avoiding and refusing eye contact with strangers last several hours to several days before the child enters the phase of despair, and the phase of release.

Factors affecting child anxiety in addition to the trauma response when given Intravenous Therapy, especially those that are invasive, among others, according to Moersintowarti (2008), namely: hospital environment, typical smell of drugs, medical devices, and health workers who are not known by child.

Bibliotherapy is proven to be able to reduce anxiety in children, even though it is done simply with or without involving parents directly. The results of this study indicate that the Anxious Response of Children aged 3-12 years after being given a Bibliotherapy who experience severe anxiety becomes $31.2 \%$ with a score range of $0-3$ and an average of 1.5 . This shows that there was a decrease in the average anxiety of $2.75(65 \%)$ after being given Bibliotherapy.

The decrease in anxiety that occurs specifically also occurs in situations where children do not flinch when their hands are touched by nurses and show interest in activities / invited to interact 93.8\%, children do not avoid when nurses come over / anticipate fear with a percentage of $80.1 \%$, children not crying loudly / groaning when given 60\% intravenous therapy, the child's breathing pattern becomes regular / no longer choked with a percentage decrease of $58.4 \%$, and the child's voice is not shaky / not frowning when given a $40 \%$ nursing intervention.

The results of statistical analysis using the Wilcoxon test, of the 16 respondents it was known that there were 15 respondents (94\%) who experienced a decrease in anxiety after being given Bibliotherapy, and 1 respondent (6\%) whose anxiety remained. Value $\mathrm{p}=0.001(\mathrm{p}<0.05)$ which means $\mathrm{H}$ berarti is rejected. So that it can be concluded that there is a difference in the Anxiety Decrease in Children aged 3-12 years when given Intravenous Therapy in the Children's Room of Ratu Zalecha Martapura Hospital in 2015 before and after being given the Bibliotherapy. The results of this study are in accordance with the results of previous studies by Anita Apriliawati (2011) which states that there is an influence of bibliotherapy on the decrease in anxiety levels in children undergoing hospitalization with a value $(p=0,000)$ and an average decrease in anxiety level of 5.33 .

Bibliotherapy is able to reduce anxiety because it is projection, especially by using imaginative or creative short stories referring to the presentation of human behavior in a dramatic way related to the situation of hospitalization experienced by children combined with illustrated fairy tales. This is in accordance with the opinion of Austin (2010) that Bibliotherapy aims to support children's needs in processing difficult personal experiences such as painful and confusing experiences for children. So that it can help overcome emotional problems / anxiety and mental children (Lucas \& Soares, 2013).

Bibliotherapy also affects children's perceptions of the nursing process in the hospital by describing that all actions given to children are not a thing to hurt and punish, but to help children recover from their illness immediately and be able to return home so they can play back with friends -friend. This is 
important, because children aged 3-12 years are still in the process of growth and development, and are included in the stage of play. Mansur (2007) argues that children use basic movement skills (running, walking, climbing, jumping, etc.), are able to communicate better with other children, enjoy playing real-life situations as part of their play.

Decreasing anxiety through bibliotherapy due to using approach techniques using therapeutic communication that can involve parents directly. This is like playing for children, where children can express their imagination through seeing pictures contained in the book and listening to the stories read by the child's nurse / parents. Differences in the effectiveness of music therapy with bibliotherapy on decreasing anxiety in 3-12 year-old Children Patients given Intravenous Therapy in the Children's Room of Ratu Zalecha Martapura Hospital in 2015

The results of the statistical analysis with the Independent Sample $\mathrm{T}$ Test obtained the value of $\mathrm{t}$ count 0.12 and the value of $p=0.91(p>0.05)$ which means $\mathrm{H}_{\mathrm{o}}$ is accepted, so it can be concluded that There is no Difference in Anxiety Decreases in Children Aged 3-12 Intravenous Therapy was given at the Children's Room of Ratu Zalecha Martapura Regional Hospital in 2015 which had previously been given Music Therapy with those given by bibliotherapy. But on average Bibliotherapy is able to reduce child anxiety by $65 \%$ compared to $57 \%$ music therapy.

Various anxiety responses that occur in the child such as trying to avoid when the nurse comes over / anticipates fear, the child jerks when his hand is touched by the nurse, the child's voice is shaky / and or crying when given nursing intervention, does not show interest in interacting (looks weak), rapid breathing / choking when given a nursing intervention, and showing facial expressions that fear is expected not to occur when the child is given Intravenous Therapy. Because it can cause tension, fear and can cause emotional or behavioral disorders that ultimately affect healing and the journey of the child's illness while being hospitalized (Posted, 2009).

Bibliotherapy is better able to reduce anxiety due to direct contact between nurses and pediatric patients, so that communication takes place more effectively therapeutically in both parents and children. It is important to change the child's view of what the nurse does just to cure the sick. This is in accordance with the study of Nelko, Greta J.P, and Franl (2013) regarding the relationship between nurse communication and stress of hospitalization in children aged 6-12 years.

Therapeutic communication also involves many senses that are used by children to project what is dismissed by nurses, especially when given Bibliotherapy with almost the same situation experienced by children, compared to music therapy which only involves the sense of hearing. This is in accordance with associative learning theory which states that the more senses (stimulus) are involved in the learning process, the child will be better able to understand the situation they are experiencing.

The age factor of the respondents who were given bibliotherapy, the majority of 6-12 years, $68.8 \%$ were more able to understand the meaning of the stories conveyed by the researchers. This is in accordance with the theory that states children aged 6-12 years get the basics of knowledge that are considered important for the success of self-adjustment in adult life, learn certain important skills, both curricular and extra-curricular skills (Wong, 2009).

The results of this study can be applied in hospitals as a complementary therapy to reduce children's anxiety during the hospitalization process. The results of this study can also be used as reference material for future researchers to be able to use more samples and different research designs such as using religious music or transcultural aspects of nursing.

\section{CONCLUSION}

Bibliotherapy can reduce anxiety in children who will be given intravenous therapy compared to music therapy. The results of this study can be applied in hospitals as complementary therapies to reduce children's anxiety during the hospitalization process and can be used as reference material for future researchers to be able to use more samples and different research designs such as using religious music or transcultural aspects of nursing.

The next researcher can further examine the use of Music Therapy and Bibliography for anxiety, pain, cooperative level by considering the same characteristics of the child and the support system of the child's parents.

\section{REFERENCES}

Aidar, N. (2011). Relationship between the Role of Families and the Anxiety Level of School-Age Children (6-12 Years Old) Who Have Hospitalization in Room III of the General Hospital Dr. Pirngadi Medan.

Debra L. Price, MSN, RN, CPNP and Julie F. Gwin, MN, R. (2012). Pediatric Nursing, 11th Edition. Saunders.

Donna L. Wong [et.all]. (2008). Wong Volume 2 Pediatric Nursing Textbook. Jakarta: EGC.

Ghabeli, F., Moheb, N., \& Hosseini Nasab, S. D. (2014). Effect of Toys and Preoperative Visit on Reducing Children's Anxiety and their Parents before Surgery and Satisfaction with the Treatment Process. Journal of Caring Sciences, $3(1)$, https://doi.org/10.5681/jcs.2014.003

Gosia M. Brykczynska, J. S. (2011). Ethical and Philosophical Aspects of Nursing Children and Young People. Wiley-Blackwell.

Judarwanto, W. (2005). The general health problems of school-age children are presented at scientific seminars on popular health in school-age children.

Kain ZN1, Mayes LC, Caldwell-Andrews AA, Karas DE, 
M. B. (2006). Preoperative anxiety, postoperative pain, and behavioral recovery in young children undergoing surgery. Pediatrics, 2. https://doi.org/10.1542/peds.2005-2920

Lucas, C. V., \& Soares, L. (2013). Bibliotherapy: A tool to promote children's psychological well-being. Journal of Poetry Therapy, 26(3), 137-147. https://doi.org/10.1080/08893675.2013.8233 10

Maratos, A., Gold, C., Wang, X., \& Crawford, M. (2008). Music therapy for depression Cochrane Database of Systematic Reviews. (1.Art). https://doi.org/10.1002/14651858.CD004517 .pub2

Musbikin, I. (2009). Greatness of Music for Sharpening Children's Intelligence. Diva Press.

Nicki L. Potts, B. L. M. (2011). Pediatric Nursing: Caring for Children and Their Families. Cengage Learning; 3 edition.

Scholten \& Randall. (2013). Anxiety Disorders (Chronic Free-Floating Anxiety).

Wilson, M. H. C. R. D. (2016). Wong's Essentials of Pediatric Nursing 10th Edition. Mosby.

Yupi Supartini . Msc. (2004). Textbook for Basic Concepts of Child Nursing. Jakarta: EGC. 